\title{
A Hashimoto-thyreoiditisben kialakuló papillaris pajzsmirigy-carcinoma klinikopatológiai jellegzetességei
}

\author{
Molnár Sarolta dr. ${ }^{1}$ - Győry Ferenc dr. ${ }^{2}$ - Nagy Endre dr. ${ }^{3}$ \\ Méhes Gábor dr. ${ }^{1}$. Molnár Csaba dr. ${ }^{1}$ \\ Debreceni Egyetem, Általános Orvostudományi Kar, ${ }^{1}$ Patológiai Intézet, ${ }^{2}$ Sebészeti Intézet, \\ ${ }^{3}$ Belgyógyászati Intézet, Debrecen
}

\begin{abstract}
Bevezetés és célkitüzés: Egyes felmérések szerint Hashimoto-thyreoiditises érintettség esetén a papillaris pajzsmirigycarcinoma gyakoribb, stádiuma pedig kevésbé előrehaladott, mint Hashimoto-thyreoiditis nélkül. Kutatásunkban a két betegség összefüggéseit vizsgáltuk az északkelet-magyarországi régióban. Betegek és módszer: Vizsgálatunk során a 2007 és 2012 között a Debreceni Egyetem, Klinikai Központ, Sebészeti Intézetben operált 230 papillaris pajzsmirigy-carcinomás beteg adatait elemeztük. Vizsgált paramétereink a nem, életkor, szövettani típus, multifokalitás és stádium voltak. Eredmények: Eseteink között 40 (17,4\%) Hashimoto-thyreoiditises (4 férfi, 36 nő) és 190 (82,6\%) Hashimoto-thyreoiditis nélküli papillaris pajzsmirigy-carcinomás (44 férfi, 146 nő) szerepelt. A papillaris carcinoma lényegesen gyakrabban bizonyult multifokálisnak Hashimoto-thyreoiditisben (16/40;40,0\%), mint nélküle (45/190; $23,7 \% ; \mathrm{p}=0,034)$. A papillaris carcinoma ugyanakkor szignifikánsan ritkábban érintette a nyirokcsomókat HT-vel társult esetekben (4 pNl [36,4\%]; 7 pN0 [63,6\%]), mint HT nélkül (34 pNl [82,9\%]; 7 pN0 [17,1\%]; p = 0,002). Következtetés: A gyakori előfordulás és a mindkét betegség fennállta esetén gyakoribb multifokális daganatképződés arra utal, hogy a Hashimoto-thyreoiditis hajlamosít papillaris pajzsmirigy-carcinoma kialakulására, azonban ennek a kapcsolatnak a biológiai háttere egyelőre nem tisztázott. Orv. Hetil., 2017, 158(5), 178-182.
\end{abstract}

Kulcsszavak: Hashimoto-thyreoiditis, papillaris pajzsmirigy-carcinoma

\section{Clinico-pathological features of papillary thyroid cancer coexistent with Hashimoto's thyroiditis}

Introduction and aim: Former studies suggest the frequent coexistence of Hashimoto's thyreoditis with papillary thyroid cancer, frequently featured by multifocal carcinogenesis but lower clinical stages compared to thyroid cancers lacking thyroiditis. We examined the clinico-pathological correlations between Hashimoto's thyroditis and papillary thyroid cancer in our region in the North-Eastern part of Hungary. Patients and method: We included a total of 230 patients with papillary thyroid cancer who underwent thyroid surgery at the Surgical Department of the University of Debrecen. Patients' sex, age, multifocality of thyroid cancer and clinical stage were evaluated. Results: Cases included 40 patients (17.4\%) with (4 male, 36 female) and $190(82.6 \%)$ patients without HT (44 male, 146 female). Hashimoto's thyroiditis related thyroid cancer was almost exclusively associated with the papillary histological type. Multifocality of papillary cancer was significantly more frequent with coexisting Hashimoto's thyroiditis (16/40; $40.0 \%)$ compared to cases uninvolved $(45 / 190 ; 23.7 \% ; \mathrm{p}=0.034)$. In contrast, lymph node metastasis was significantly less frequent among patients with Hashimoto's thyroiditis (4 pNl [36.4\%]; 7 pN0 [63.6\%]) then without it $(34 \mathrm{pNl}$ [82.9\%]; 7 pN0 [17.1\%]; p = 0.002). Conclusion: Higher frequency and multifocality of papillary thyroid cancer might be the consequence of preexisting Hashimoto's thyroiditis to be considered as a preneoplastic stimulus supporting carcinogenesis, though the exact pathomechanism of this correlation is not clear yet.

Keywords: Hashimoto's thyroiditis, thyroid cancer, papillary

Molnár, S., Györy, F., Nagy, E., Méhes, G., Molnár, Cs. [Clinico-pathological features of papillary thyroid cancer coexistent with Hashimoto's thyroiditis]. Orv. Hetil., 2017, 158(5), 178-182.

(Beérkezett: 2016. október 18.; elfogadva: 2016. december 12.) 


\section{Rövidítések}

$\mathrm{HT}=$ Hashimoto-thyreoiditis; $\mathrm{MF}=$ multifokális $; \mathrm{PPC}=$ papillaris pajzsmirigy-carcinoma; UF = unifokális

A Hashimoto-thyreoiditis (HT) a pajzsmirigy állományát érintő szervspecifikus autoimmun betegség, amely a mirigyállomány fokozatos destrukciójával párhuzamosan hipofunkciós klinikai tünetekhez, emelkedett TSH-, csökkent $\mathrm{T}_{3}$ - és $\mathrm{T}_{4}$-szinttel járó pajzsmirigy-múködészavarhoz vezet. A HT klinikai diagnózisa a specifikus autoantitestek jelenlétén alapul, azonban a hiperergiás immunológiai folyamatok következményei szövettani vizsgálat kapcsán is jól követhetők [1-3].

A pajzsmirigy-carcinoma a leggyakoribb malignus endokrin tumorok közé tartozik [4]. Döntő többségét $(87,9 \%)$ a papillaris pajzsmirigy-carcinoma (PPC) szövettani típus teszi ki [5], emellett ritkábban follicularis, medullaris és anaplasztikus pajzsmirigyrák is jelentkezhet. A PPC diagnózisa a térfoglaló pajzsmirigyfolyamat kórszövettani vizsgálatán alapul. Kialakulásában eddig bizonyított módon egyedül az ionizáló sugárzás játszik szerepet [6-8]. Az esetek egy részében ugyanakkor a PPC a mirigyállományon belül különböző területekből, egyidejúleg több gócból is növekedésnek indulhat, ami valamely fölérendelt okot feltételez.

Néhány korábbi kohorszvizsgálat úgy találta, hogy a PPC gyakrabban jelentkezik HT-s betegeknél, mint a HT-ben nem érintett betegek körében [9-12], azonban mások ezt vitathatónak tartották [13-15]. A két betegség közötti asszociációt modernebb szemléletű keresztmetszeti vizsgálatok egyértelmúbben támasztják alá, öszszességében mára elfogadott tény a PPC és a HT összefüggése [16-29]. Bár e kapcsolat molekuláris patomechanizmusa nem tisztázott, más malignus daganatok esetében bebizonyosodott már, hogy a krónikus gyulladással párhuzamosan - a szöveti destrukciót követô regenerációban - a sejtproliferációt indukáló jelátviteli útvonalak aktiválása malignus transzformációhoz vezethet.

A pajzsmirigyrák az esetek egy részében egyszerre több helyen, multifokális (MF) jelleggel alakul ki a pajzsmirigyben. Egy nemrégiben publikált metaanalízis alapján a PPC multifokalitása szignifikánsan gyakoribb HT-s érintettség esetén, mint nélküle $[16,17,23,30]$. Egyesek szerint a PPC tumor- $[26,31,32]$ és nyirokcsomóstádiuma [31] ugyanakkor kisebb HT-s érintettség esetén. A PPC-ben és HT-ben is érintett betegek között néhány vizsgálat szerint erőteljesebb a női predominancia $[23,26,31]$ és kisebb az átlagéletkor [31], mint a csak PPC-ben érintett betegek körében.

\section{Célkitüzések}

Kutatásunk célja a PPC és a HT közötti összefüggés vizsgálata a kelet-magyarországi térségben. Az általunk felvetett kérdések egy része arra vonatkozik, hogy a HT fennállása milyen mértékben jár a PPC kockázatával, és az együttes előfordulás milyen klinikopatológiai jellegzetességeket mutat. Vizsgálataink keretében azt is megvizsgáltuk, hogy gyakoribb-e a HT-vel kísért PPC-sek körében a tumor multifokalitása.

\section{Betegek és módszer}

A vizsgálatba a Debreceni Egyetem, Klinikai Központ Sebészeti Intézetében 2007 és 2012 között pajzsmirigybetegség miatt mütött betegek szövettani anyagát vizsgáltuk meg újra. A Medical Solutions kórházi nyilvántartási program segítségével adatbázisunkból kikerestük a malignus pajzsmirigytumor végdiagnózisú eseteket. A follicularis, medullaris és anaplasztikus pajzsmirigyrákos esetek, valamint a pajzsmirigy rosszindulatú, de nem hámeredetű tumorai nem kerültek további elemzésre. További vizsgálatainkat olyan szövetmintákon végeztük, amelyek reprezentatív pajzsmirigyállományt tartalmaztak a HT fennállásának megítélése céljából. Az így kialakított vizsgálati populáció 230 PPC-s betegből áll. Közülük összesen 40 esetben (4 férfi [10\%]; 36 nő [90\%]) találtuk meg a HT szöveti érintettségének egyértelmü jeleit. A HT nélküli PPC-s csoportba 190 beteg, nemi megoszlás szerint 44 férfi $(23,1 \%)$ és 146 nő $(76,8 \%)$ került.

A szövettani mintákat a Debreceni Egyetem, Klinikai Központ Patológiai Intézetében egységes véleményezést követően osztályoztuk. A HT szövettani diagnózisát akkor mondtuk ki, ha a hematoxilin-eozin festett metszetekben krónikus lobsejtes beszürődés, másodlagos nyiroktüszők és follicularis atrophia volt látható. Számos esetben megerősítette a diagnózist a Hürthle-sejtes metaplasia jelenléte is. A PPC diagnózisa a neoplasztikus sejtekben felismerhető sejtmag-morfológiai eltéréseken (magmegnagyobbodás, magtorlódás, tejüveghomály, egyenetlen és irreguláris magkontúr, magbarázda, pseudoinclusiók) alapult, valamint megerósítette azt a jellegzetes papillaris citoarchitektúra és a psammoma-testek jelenléte is. A hematoxilin-eozin festett metszetek mellett kiegészítő immunhisztokémiai vizsgálatokat végeztünk a HBME-1, a galectin-3 és a CK-19 szöveti antigének kimutatására, amelyek a PPC-sejtcsoportok azonosítását szolgálták. A pajzsmirigyrák többgócú jellege valamennyi, a sebészi pajzsmirigy-preparátumból készített metszet áttekintése kapcsán az egyes gócok dokumentálása után került megállapításra.

A szöveti és klinikopatológiai adatokat statisztikailag értékeltük: az átlagéletkort t-próbával, a férfi/nő arány, a multifokalitás, a nyirokcsomó-érintettség és a nyirokcsomó-dissectio összefüggésében $\chi^{2}$-próbát alkalmaztunk. A tumor- és TNM-stádiumot Mann-Whitney-próbákkal hasonlítottuk össze. 


\section{Eredmények}

A PPC-s betegek között szignifikánsan magasabb volt a nők aránya HT-s érintettség esetén (4 férfi [10\%]; 36 nő [90\%]), mint a nélkül (44 férfi $[23,1 \%] ; 146$ nő $[76,8 \%]$; $\mathrm{p}=0,046)$. Eredményeinket az 1. táblázat mutatja be.

A többgócú PPC gyakoriságát szignifikánsan befolyásolta a HT-s érintettség: A PPC és HT együttes fennállása esetén szignifikánsan gyakoribb volt a multifokalitás (16/40 MF [40,0\%]), mint a HT nélküli PPC-s betegpopulációban $(45 / 190 \mathrm{MF}[23,7 \%] ; \mathrm{p}=0,034)$.

A PC klinikopatológiai megjelenésében is megfigyelhetô volt néhány eltérés. A PPC-ben és HT-ben egyaránt érintett betegek tumorstádiuma nem különbözik $(\mathrm{M}=$ $1,33 \pm 0,73 \mathrm{SD})$ a HT nélküli PPC-sekétől $(\mathrm{M}=$ $1,48 \pm 0,76 ; \mathrm{p}=0,065)$. A PPC-ben és HT-ben érintett 40 betegből 11 esetben $(27,5 \%)$, a PPC-ben igen, de HT-ben nem érintett 190 betegből 41 esetben $(21,6 \%)$ történt a mútét során nyaki nyirokcsomó-dissectio. A papillaris carcinoma szignifikánsan ritkábban érintette a nyirokcsomókat HT-vel társult esetekben (4 pNl $[36,4 \%] ; 7$ pN0 [63,6\%]), mint HT nélkül (34 pNl $[82,9 \%] ; 7$ pN0 [17,1\%]; p =0,002). A TNM-stádium nem mutatott összefüggést a HT-s anamnézissel.

\section{Megbeszélés}

Tanulmányunkban a populációs szinten meglehetősen gyakori HT és a PPC megjelenése közötti összefüggéseket vizsgáltuk klinikopatológiai szempontok szerint. Első hazai eredményeink azt mutatták, hogy a nemzetközi szakirodalomban közzétett tanulmányoknak megfelelően HT-s érintettség esetén gyakoribb a PPC multifokalitása, mint HT-s érintettség nélkül.

Kézenfekvő, hogy a HT és a PPC kapcsolatában egyes konkrét genetikai/biológiai szempontokat alaposabban megvizsgáljunk. A leggyakoribb, PPC-vel társuló kromoszómaaberrációk következményeként a RET/PTCl, illetve a RET/PTC3 fúziós génekról átírt mRNS jelenléte RT-PCR-rel kimutatható [33]. A RET onkogén aktiválja

1. táblázat | Eredményeink

\begin{tabular}{llll}
\hline Vizsgált paraméter & Tumor + HT & Tumor HT nélkül & p-érték \\
\hline Nem (férfi/nő) & $4 / 36(10,0 \%)$ & $44 / 146(23,1 \%)$ & $0,046^{*}$ \\
\hline Életkor (év) & $44,03 \pm 16,18$ & $48,03 \pm 16,74$ & 0,168 \\
\hline $\begin{array}{l}\text { Multifokalitás } \\
\text { (MF/UF) }\end{array}$ & $16 / 24(40,0 \%)$ & $45 / 145(23,7 \%)$ & $0,034^{*}$ \\
\hline pT & $1,33 \pm 0,73$ & $1,48 \pm 0,76$ & 0,065 \\
\hline pN (pN0/pNl) & $7 / 4(63,6 \%)$ & $7 / 34(17,1 \%)$ & $0,002^{*}$ \\
\hline TNM & $1,20 \pm 0,61$ & $1,33 \pm 0,79$ & 0,197 \\
\hline
\end{tabular}

A táblázatban a papillaris pajzsmirigy-carcinomás betegeket HT-s (Hashimoto-thyreoiditises) és nem HT-s alcsoportokra bontva a nem, a kor, a multifokalitás, a tumor-, nyirokcsomó- és TNM-stádium öszszefüggéseit mutatjuk be a HT-vel. a p2lras-t, ami foszforilálja a BRAF-ot, ami egy mitogén aktiválta proteint foszforilál. Wirtschafter és mtsai felvetették a RET gén aktivációjának lehetőségét HT-ben is (leggyakoribb a PTCl és a PTC3 génfúzió). Arra a meglepő eredményre jutottak, hogy a HT kapcsolata a fenti kromoszómaaberrációkkal legalább olyan szoros, mint a PPC-ben [34]. Az ebből következő hipotézis szerint a RET gén aberrációja és patológiás expressziója a follicularis hámsejtekben (thyreocytákban) a transzformáló hatás mellett befolyásolja a sejtek antigenitását, ami a korai szakban HT megjelenéséhez vezethet.

A BRAF mutációi a PPC-ben előforduló leggyakoribb genetikai eltérések. A BRAF V600E-mutáció hajlamosít a tumor multifokalitására, a pajzsmirigyen kívüli terjedésre, a nyirokcsomó-metasztázis kialakulására és az előrehaladottabb tumorstádiumra [35]. Úgy tûnik azonban, hogy ez a mutáció nem magyarázhatja a HT és PPC összefüggését, mert az eddigi adatok alapján ritkábban detektálható HT-vel kísért PPC esetén, mint HT nélkül [36].

Az előző aktiváló mechanizmusokon túl a PI3K/Akt jelátviteli útvonal aktivitása is megnövekedhet HT-ben. A normális thyreocytákban nem, HT esetén viszont a thyreocytákban és a lymphocytákban egyaránt, és természetesen a PPC daganatsejtekben is fokozódik az Aktfoszforiláció [37]. A PI3K inhibitorát, a PTEN-t fiziológiásan expresszálják a normális, valamint a HT-ben érintett thyreocyták is, viszont nem expresszálják a PPC-s transzformált folliculushámsejtek. A HT-ben és PPCben egyaránt érintett mintákban intermedier mértékű PTEN-expresszióról számoltak be [36]. A PI3K/Akt útvonal a pro- és antiapoptotikus szignálok közti egyensúly fenntartásában és a gyulladásos folyamatok irányításában játszik szerepet. Ezek alapján feltételezhető, hogy az egyik kulcslépés a HT talaján létrejövő PPC kialakulásában a PI3K aktivitásának fokozódása, ami a proapoptotikus szignálok elnyomásához vezethet.

Molekuláris szinten összekapcsolhatja a HT-t a PPCvel a p53-mal homológ p63 fehérje, amely egyfajta ôssejtfenotípus fenntartásáért felelős. Alternatív splicing segítségével ugyanis létrejöhet egy kisebb, csonka p63 molekula, ami a tumorszuppresszor p53 kompetitív inhibitora. Fiziológiás körülmények között, valamint strúmában, Graves-Basedow-kórban, illetve follicularis adenoma esetén a thyreocyták p63-at nem expresszálnak. Ezzel szemben PPC-ben, főleg a papillált szerkezetü klasszikus variánsban és HT-ben is, az esetek nagy részében fokálisan megfigyelhető a p63-expresszió [38]. A fentiek alapján a HT vezethet a PPC kialakulásához a p63 indukciójának közbeiktatásával vagy a p63-túlexpresszió vezethet mindkét betegség kialakulásához a tumoros elfajulás és a gyulladásos folyamatok párhuzamos beindításával.

A HT-ben jelentkező autoimmun mechanizmusok a pajzsmirigy egész állományára hatással vannak. A follicularis hámot érő destruktív folyamat a mirigyállomány számos pontján, egymástól függetlenül idézi elő a 
thyreocyták adaptív jellegú aktivációját, ami a fent részletezett bonyolult mechanizmusok következtében fokozott transzformációs hajlammal is jár, akár több, egymástól független tumoros fókuszt létrehozva. A fölérendelt mechanizmus lényegében megfelel a daganatbiológiában ismert úgynevezett field cancerization jelenségének, amelyet jelen esetben leginkább a fokozott TSH-hatás és a gyulladásos citokinek és a feltételezett genetikai-biológiai hatások együttesen váltanak ki. Ennek megfelelően vizsgálatainkban is nagyobbnak találtuk a multifokális PPC arányát HT-s érintettség esetén, mint a nélkül. Bár az egyes beszámolók ellentmondásosak, az irodalomban ezeknek a kutatásoknak az alapján készült metaanalízis szerint a különbség szignifikáns [23]. Az azonban még nem teljesen világos, hogy vajon minden esetben egymástól teljesen függetlenül alakultak-e ki a tumoros gócok. Elképzelhető például az is, hogy a HT-val asszociált primer PPC progressziója során hajlamos a szerven belül izolált metasztázisokat képezni. A kérdés megválaszolásában a későbbiekben segíthet a különböző helyekről származó daganatsejtek mutációinak, kromoszómaaberrációinak vagy a velük összefüggésben expresszált markereinek az összehasonlítása, hiszen megmutathatják, hogy a tumorsejt-populációk a tumorigenezis melyik fázisában váltak el egymástól.

További érdekes kérdés, hogy miért viszonylag jóindulatúbb viselkedésű a HT-vel kísért PPC, mint a HT nélküli. A tumor patológiai stádiuma (átmérő) a legtöbb vizsgálat alapján függetlennek bizonyul a HT-től, azonban a pajzsmirigyen kívüli terjedés és a nyirokcsomóérintettség ellen a HT protektív hatással jár [31]. A mi adataink alapján is szignifikánsan alacsonyabb a PPC-sek között azoknak a nyirokcsomó-stádiuma, akik HT-ben is érintettek. Esetünkben a jelenség magyarázatául szolgálhatna, ha a HT valamelyest kisebb tumorstádiummal jár, azonban mindegyik tumorstádium esetén, egyenként elvégezve a $\chi^{2}$-próbát is, szignifikáns a fenti összefüggés. A nyirokcsomóstátuszt és akár a beteg túlélését is jelentősen befolyásolhatja a megnagyobbodott nyirokcsomók megléte, ami HT esetén a gyulladás és immunaktivitás miatt eleve fennállhat és a nagyobb méret sebészi azonosításukat is megkönnyíti. Arra vonatkozóan azonban, hogy eseteinkben mennyi és mekkora nyirokcsomó került eltávolításra, adatbázisunk alapján nem tudtunk megbízható formában válaszolni.

A PPC progressziója és a HT fennállása közötti összefüggésre ezek után azt találjuk a legkézenfekvőbb magyarázatnak, hogy a HT a diagnózis felállításától folyamatosan szoros monitorozást igénylő betegség, a kontrollvizsgálatok során a pajzsmirigyállomány tapintási, illetve ultrahangos ellenőrzése már jóval korábban lehetővé teszi új jelenségek, például izolált göbök felismerését.

\section{Következtetés}

Kutatásunkban a HT és PPC közti összefüggéseket vizsgáltuk klinikopatológiai betegadatok elemzésével. HT esetében a PPC gyakoribb és gyakrabban multifokális, ami arra utal, hogy a HT a PPC megelőző állapotának tekinthető. Ilyen esetekben a PPC az alapbetegség folyamatos gondozása kapcsán hamarabb felismerésre kerülhet, ami a metasztatikus PPC megelőzéséhez is hozzájárul. A szóba jöhető sokféle immunológiai és molekuláris mechanizmus pontosabb megismerésével a PPC korai diagnózisa, predikciója is hatékonyabban történhet majd.

Anyagi támogatás: A közlemény megírása, illetve a kapcsolódó kutatómunka anyagi támogatásban nem részesült.

Szerzôi munkamegosztás: M. G., Gy. F., N. E., M. Cs., M. S.: A hipotézisek kidolgozása. M. Cs.: A vizsgálat lefolytatása. M. S.: Statisztikai elemzések. M. G., M. S.: A kézirat megszövegezése. A cikk végleges változatát valamennyi szerző elolvasta és jóváhagyta.

Érdekeltségek: A szerzőknek nincsenek érdekeltségeik.

\section{Irodalom}

[1] Dong, Y. H., Fu, D. G.: Autoimmune thyroid disease: mechanism, genetics and current knowledge. Eur. Rev. Med. Pharmacol. Sci., 2014, 18(23), 3611-3618.

[2] Ajjan, R. A., Weetman, A. P.: The pathogenesis of Hashimoto's thyreoiditis: further developments in our understanding. Horm. Metab. Res., 2015, 47(10), 702-710.

[3] Pyzik, A., Grywalska, E., Matyjaszek-Matuszek, B., et al.: Immune disorders in Hashimoto's thyroiditis: what do we know so far? J. Immunol. Res., 2015, 2015, ID 979167.

[4] http://seer.cancer.gov/csr/1975_2011/browse_csr.php?sectio nSEL=26\&amp;pageSEL=sect_26_table.05.html

[5] http://seer.cancer.gov/csr/1975_2011/browse_csr.php?sectio $\mathrm{nSEL}=26$ \&amp;pageSEL=sect_26_table.22.html

[6] Cardis, E., Howe, G., Ron, E., et al.: Cancer consequences of the Chernobyl accident: 20 years on. J. Radiol. Prot., 2006, 26(2), 127-140.

[7] Ron, E., Lubin, J. H., Shore, R. E., et al.: Thyroid cancer after exposure to external radiation: a pooled analysis of seven studies. Radiat. Res., 1995, 178(2), 43-60.

[8] Nikiforov, $\Upsilon$. E.: Radiation-induced thyroid cancer: what we have learned from Chernobyl. Endocr. Pathol., 2006, 17(4), 307317.

[9] Dailey, M. E., Lindsay, S., Skaben, R.: Relation of thyroid neoplasms to Hashimoto disease of thyroid gland. AMA Arch. Surg., 1955, 70(2), 291-297.

[10] Chesky, V. E., Hellwig, C. A., Welch, J. V.: Cancer of the thyroid associated with Hashimoto's disease: an analysis of forty-eight cases. Am. Surg., 1962, 28, 678-685.

[11] Meier, D. W., Woolner, L. B., Beahrs, O. H., et al.: Parenchymal findings in thyroidal carcinoma: pathologic study of 256 cases. J. Clin. Endocrinol. Metab., 1959, 19(1), 162-171.

[12] Shands, W. C.: Carcinoma of the thyroid in association with struma lymphomatosa (Hashimoto's disease). Ann. Surg., 1960, 151(5), 675-681.

[13] Crile, G. Jv., Hazard, J. B.: Incidence of cancer in struma lymphomatosa. Surg. Gynecol. Obstet., 1962, 115, 101-103.

[14] Crile, G. Jr.: Struma lymphomatosa and carcinoma of the thyroid. Surg. Gynecol. Obstet., 1978, 147(3), 350-352. 
[15] Holm, L. E., Blomgren, H. L., Löwhagen, T.: Cancer risks in patients with chronic lymphocytic thyroiditis. N. Engl. J. Med., 1985, 312(10), 601-604.

[16] Kim, K. W., Park, Y. J., Kim, E. H., et al.: Elevated risk of papillary thyroid cancer in Korean patients with Hashimoto's thyroiditis. Head Neck, 2011, 33(5), 691-695.

[17] Consorti, F., Loponte, M., Milazzo, F., et al.: Risk of malignancy from thyroid nodular disease as an element of clinical management of patients with Hashimoto's thyroiditis. Eur. Surg. Res., 2010, 45(3-4), 333-337.

[18] Fiore, E., Rago, T., Scutari, M., et al.: Papillary thyroid cancer, although strongly associated with lymphocytic infiltration on histology, is only weakly predicted by serum thyroid auto-antibodies in patients with nodular thyroid diseases. J. Endocrinol. Invest., 2009, 32(4), 344-351.

[19] Kurukabvecioglu, O., Taneri, F., Yüksel, O., et al.: Total thyreoidectomy for the treatment of Hashimoto's thyroiditis coexisting with papillary thyroid carcinoma. Adv. Ther., 2007, 24(3), 510516.

[20] Cipolla, C., Sandonato, L., Graceffa, G., et al.: Hashimoto thyroiditis coexistent with papillary thyroid carcinoma. Am. Surg., 2005, 7l(10), 874-878.

[21] Tamimi, D. M.: The association between chronic lymphocytic thyroiditis and thyroid tumors. Int. J. Surg. Pathol., 2002, 10(2), 141-146.

[22] Okayashu, I., Fujiwara, M., Hara, Ү., et al.: Association of chronic lymphocytic thyroiditis and thyroid papillary carcinoma. A study of surgical cases among Japanese, and white and African Americans. Cancer, 1995, 76(11), 2312-2318.

[23] Lee, J. H., Kim, Y., Choi, J. W., et al.: The association between papillary thyroid carcinoma and histologically proven Hashimoto's thyroiditis: a meta-analysis. Eur. J. Endocrinol., 2013, $168(3), 343-349$.

[24] Mazokopakis, E. E., Tzortzinis, A. A., Dalieraki-Ott, E. I., et al.: Coexistence of Hashimoto's thyroiditis with papillary thyroid carcinoma. A retrospective study. Hormones, 2010, 9(4), 312317.

[25] Huang, B. Y., Hseuh, C., Chao, T. C., et al.: Well-differentiated thyroid carcinoma with concomitant Hashimoto's thyroiditis present with less aggressive clinical stage and low recurrence. Endocr. Pathol., 2011, 22(3), 144-149.

[26] Repplinger, D., Bargren, A., Zhang, Y. W., et al.: Is Hashimoto's thyroiditis a risk factor for papillary thyroid cancer? J. Surg. Res., 2008, 150(1), 49-52.

[27] Van Savell, H. Jr., Hughes, S. M., Bower, C., et al.: Lymphocytic infiltration in pediatric thyroid carcinomas. Pediatr. Dev. Pathol., $2004,7(5), 487-492$
[28] Harach, H. R., Escalante, D. A., Day, E. S.: Thyroid cancer and thyroiditis in Salta, Argentina: a 40-yr study in relation to iodine prophylaxis. Endocr. Pathol., 2002, 13(3), 175-181.

[29] Loh, K. C., Greenspan, F. S., Dong, F., et al.: Influence of lymphocytic thyroiditis on the prognostic outcome of patients with papillary thyroid carcinoma. J. Clin. Endocrinol. Metab., 1999, $84(2), 458-463$.

[30] Kebebew, E., Treseler, P. A., Ituarte, P. H., et al.: Coexisting chronic lymphocytic thyroiditis and papillary thyroid cancer revisited. World J. Surg., 2001, 25(5), 632-637.

[31] Yoon, צ. H., Kim, H. J., Lee, J. W., et al.: The clinicopathologic differences in papillary thyroid carcinoma with or without coexisting chronic lymphocytic thyroiditis. Eur. Arch. Otorhinolaryngol., 2012, 269(3), 1013-1017.

[32] Konturek, A., Barczyński, M., Wierzchowski, W., et al.: Coexistence of papillary thyroid cancer with Hashimoto thyroiditis. Langenbeck's Arc. Surg., 2013, 383(3), 389-394.

[33] Nikiforov, $\Upsilon$. E.: RET/PTC rearrangement in thyroid tumors. Endocr. Pathol., 2002, 13(1), 3-16.

[34] Wirtschafter, A., Schmidt, R., Rosen, D., et al.: Expression of RET/PTC fusion gene as a marker for papillary carcinoma in Hashimoto's thyroiditis. Laryngoscope, 1997, 107(1), 95-100.

[35] Li, F., Chen, G., Sheng, C., et. al.: BRAFV600E mutation in papillary thyroid microcarcinoma: a meta-analysis. Endocr. Relat. Cancer, 2015, 22(2), 159-168.

[36] Kim, S. J., Myong, J. P., Jee, H. G., et al.: Conbined effect of Hashimoto's thyroiditis and BRAF(V600E) mutation status on aggressiveness in papillary thyroid cancer. Head Neck, 2016, $38(1), 95-101$.

[37] Larson, S. D., Jackson, L. N., Riall, T. S., et al.: Increased incidence of well-differentiated thyroid cancer associated with Hashimoto thyroiditis and the role of the PI3K/Akt pathway. J. Am. Coll. Surg., 2007, 204(5), 764-773.

[38] Unger, P., Ewart, M., Wang, B. Ү., et al.: Expression of p63 in papillary thyroid carcinoma and in Hashimoto's thyroiditis: a pathobiologic link? Hum. Pathol., 2003, 34(8), 764-769.

[39] Ma, H., Yan, J., Zhang, C., et al.: Expression of papillary thyroid carcinoma-associated molecular markers and their significance in follicular epithelial dysplasia with papillary thyroid carcinomalike nuclear alterations in Hashimoto's thyroiditis. Int. J. Clin. Exp. Pathol., 2014, 7(11), 7999-8007.

(Molnár Sarolta dr., Debrecen, Nagyerdei krt. 98., 4032 e-mail: molnar.sarolta@med.unideb.hu)

\section{"Consilium in dubiis remedium prudentis est" (Válságos helyzetben a bölcs menedéke a megfontolás.)}

